\title{
ISKRY, KTÓRE SPOWODOWAEY POŻAR. \\ TRZY WYDARZENIA, KTÓRE ZAPOCZĄTKOWAEY Ruch na Rzecz Praw Obywatelskich w Stanach Zjednoczonych
}

\author{
JULIAN JELIŃSKI \\ julian.jelinski@gmail.com
}

(@) $\odot \Theta \Theta$

Stany Zjednoczone Ameryki Północnej w pierwszej połowie XX wieku były krajem skrajnie podzielonym według jednego, uniwersalnego kryterium - kryterium koloru skóry. W stanach południowych panowała pełna, prawna segregacja, usankcjonowana orzeczeniem Sądu Najwyższego w sprawie Plessy przeciw Fergusonowi z $1896 r$ r. ${ }^{1}$ W stanach północnych zaś, segregacja miała mniej oficjalny, ale równie skrajny i wszechogarniający charakter. Nawet udział USA w obu Wojnach Światowych nie zmienił tej „specyficznej sytuacji” Afroamerykanów, mimo iż Stany Zjednoczone prowadziły obie wojny w obronie wolności, równości i demokracji. Najwyraźniej nawet równość oraz wolność były wartościami, które mogły przysługiwać w tym czasie jedynie ludziom o białym kolorze skóry. Wolność, przyznana wszystkim czarnoskórym niewolnikom w 1863 r. poprzez Deklarację Niepodległości w obliczu późniejszej dyskryminacji, segregacji i wykluczenia społecznego, wydawała się jedynie „formalną wolnością", a sama Deklaracja Niepodległości - nic nie znaczącym, symbolicznym dokumentem.

Sytuacji Czarnych ${ }^{2}$ w XX wieku nie zmieniły działania odgórne Rządu Stanów Zjednoczonych. Sami Afroamerykanie musieli wywalczyć prawa, które innym obywatelom przystugiwały z racji samego urodzenia się na terytorium USA. Ich obywatelski zryw przypadł na drugą połowę lat 50. oraz lata 60. XX wieku. Okres ten publicyści, historycy, a także sami uczestnicy ówczesnych wydarzeń określają mianem „trzeciej rewolucji amerykańskiej”, lub też Rewolucji Czarnych ${ }^{3}$. Esencjalną część owej Rewolucji stanowił Ruch na Rzecz Praw Obywatelskich (the Civil Rights Movement), którego celem było uzyskanie (a właściwie - odzyskanie) swobód obywatelskich dla Afroamerykanów.

Ruch na Rzecz Praw Obywatelskich, jak każdy inny ruch musiał mieć swój początek. W tym jednak przypadku ciężko jest wskazać na tylko jedno wydarzenie, które uwarunkowało jego powstanie - należy moim zdaniem przytoczyć aż trzy. Trzy „iskry”, które stały się katalizatorami ogólnonarodowego ruchu społecznego, w którym w ciągu dwóch dziesięcioleci uczestniczyły miliony Amerykanów. Zanim jednak opisane zostaną owe wydarzenia, warto zwrócić uwagę na jeszcze jedną kwestię, którą można uznać za „symboliczną czwartą iskrę", lub też ciąg wydarzeń, które także wpłynęły na powstanie Ruchu na Rzecz Praw Obywatelskich - proces dekolonizacji Afryki.

\footnotetext{
Decyzja Sądu Najwyższego w sprawie Plessy przeciw Fergusonowi usankcjonowała doktrynę „,oddzielni, lecz równi" (separate but equal), uznając, że nie jest ona sprzeczna z XIV poprawką do Konstytucji Stanów Zjednoczonych.

W polskiej literaturze niezmiennie ignorowany jest prawidłowy sposób określania czarnoskórych mieszkańców Ameryki Pótnocnej. Z nieznanych mi powodów, wciąż używa się terminu „Murzyn”. Najlepiej ten problem opisuje Zbigniew M. Kowalewski, gdy podkreśla, że: „(...) piszemy Czarny (Black) a nie Murzyn (Negro), gdyż ten ostatni termin, uznany przez czarną społeczność za obraźliwy i rasistowski, pod jej presją wyszedł z użycia w USA w ciagu ostatnich kilkudziesięciu lat, czego polskie mass media uparcie nie chcą przyją́ do wiadomości. W przeciwieństwie do biały piszemy Czarny z dużej litery, gdyż oznacza to przynależność do czarnego narodu, żyjącego w USA, a nazywanego również afroamerykańskim (Afro-American) afrykańsko-amerykańskim (African American) i nowoafrykańskim (New African)" - por. Z. M. Kowalewski, Rap - między Malcolmem X a subkultura gangowa, e-book, edycja 10. 02. 2008, str. 6.

3 Por. R. R. Ludwikowski, Murzyński radykalizm w USA, Warszawa 1976, s. 5.
} 
Możliwość „,obserwacji” procesu dekolonizacji państw afrykańskich wpłynęła na radykalizację podejścia Czarnych wobec społeczeństwa białych Amerykanów. Od zakończenia II Wojny Światowej, niepodległość uzyskało ponad 30 państw Afryki, zrzucając więzy ucisku kolonialnego. Znaczenie wydarzeń na odległym kontynencie podkreślali już w latach 60. XX wieku afroamerykańscy przywódcy i pisarze, w tym m.in. Martin Luther King, który stwierdzał: „Murzyna inspiruje (...) potężna siła spoza granic jego kraju. Obserwuje dekolonizację i wyzwalanie narodów Afryki i Azji po drugiej wojnie światowej (...). Na kontynencie, z którego go porwano i obrócono w niewolnika Murzyn obserwuje wielki postęp polityczny ${ }^{\prime \prime}$. O symbolicznym wpływie ruchów emancypacyjnych w Afryce pisał także James Baldwin ${ }^{5}$, jeden z najważniejszych czarnoskórych pisarzy XX wieku: „W czasach mojej młodości (przed II Wojną Światową - przyp. J. J.) Murzynów w tym kraju uczono wstydzić się Afryki. Wykładano im to brutalnie (...), mówiąc że Afryka nie wniosła »niczego« do cywilizacji. (...). Młodzi mają dziś przed sobą inny obraz. Kiedy dorośli, na arenie świata pojawiła się Afryka. (...) Te fakty nie mogły nie wywrzeć niezwykłego wpływu na ich morale, albowiem oznaczały, że nie tylko przestali być potomkami niewolników w białym, protestanckim kraju purytanów, ale że stali się również potomkami królów i książąt w swojej dawnej, dalekiej ojczyźnie" ${ }^{\prime \prime}$.

Ciężko jest określić bezpośredni wpływ dekolonizacji Afryki na postawy Afroamerykanów wobec rządu amerykańskiego i rasistowskich przepisów, jednakże niezaprzeczalne jest jego chociażby symboliczne znaczenie.

Możemy obecnie przejść do trzech wydarzeń, które zapoczątkowały ogólnonarodowy ruch społeczny mający na celu uzyskanie przez Afroamerykanów praw obywatelskich oraz zniesienie rasistowskich i dyskryminujących Czarnych praw. Wydarzenia te mają miejsce w latach 1954 - 1955 i dotyczą trzech różnych aspektów życia Afroamerykanów, w których byli oni od lat upośledzeni w stosunku do białych i dyskryminowani przez białe społeczeństwo.

Pierwszą z tytułowych „,iskier", było zaskarżenie zasad, na których opierało się segregacyjne szkolnictwo na Południu, zorganizowane głównie przez Narodowe Stowarzyszenie na Rzecz Postępu Ludzi Kolorowych (National Association for Advancement of Colored People - NAACP). Organizacja ta już na kilka lat przed omawianym procesem zaczęła zbierać dokumenty i akta ze spraw dotyczących nierówności segregowanych szkół, by móc uderzyć w cały system edukacji oparty na pełnej segregacji czarnoskórych dzieci od ich białych rówieśników. Sprawa ta, znana jako „Brown przeciw zarządowi szkół w Topeka” została roztrzygnięta 17. maja 1954 r., gdy swą decyzję wydał Sąd Najwyższy Stanów Zjednoczonych.

W wyroku tym musiano odnieść się do orzeczenia z 1896 r. w sprawie Plessy przeciw Fergusonowi, sankcjonującego segregacyjną doktrynę „oddzielni, lecz równi” (separate but equal), która stała się podstawą budowy całego systemu rozdzielającego rasy. Sąd Najwyższy uznał segregację w szkołach za niezgodną z konstytucją obalając w ten sposób obowiązującą do tej pory decyzję z przed ponad 50 lat. Sędzia przewodniczący stwierdził w uzasadnieniu m.in., że czarnoskóre dzieci, uczęszczające do segregowanych szkół są pozbawione równych szans, które

\footnotetext{
4 M. L. King, Dlaczego nie możemy czekać, Warszawa 1967, s. 18-19.

James Baldwin był pisarzem zaangażowanym politycznie i wspierających czynnie Ruch na Rzecz Praw Obywatelskich zarówno uczestnicząc w akcjach protestacyjnych, jak i pisząc na temat sytuacji Czarnych. Por. J. Baldwin, $\mathrm{Na}$ spotkanie człowieka, Warszawa 1971, J. Baldwin, Następnym razem pożar, Warszawa 1965.

6 J. Baldwin, Następnym razem..., dz. cyt., s. 94-95.

NAACP powstało w 1910 r. i szybko stało się największą organizacją walczącą o prawa Afroamerykanów, por. Por. R. R. Ludwikowski, Murzyński radykalizm..., dz. cyt., s. 19-23.
} 
gwarantuje im XIV poprawka do konstytucji. Zgodnie z wyrokiem nie tylko uznano segregację w szkołach za niezgodną z konstytucja, ale także nakazano rozpoczęcie procesu desegregacji szkolnictwa na terenie całych Stanów Zjednoczonych.

Wydarzenie to stało się symbolicznym początkiem legalistycznego aspektu Rewolucji Czarnych, na który złożyły się zmiany w ustawodawstwie zarówno federalnym jak i stanowym, wywalczone przez Afroamerykanów w przeciągu lat 1954 - 1968. Przełomowość sprawy Brown przeciw zarządowi szkół w Topeka polega przede wszystkim na tym, iż było to pierwsze zwycięstwo Afroamerykanów walczących o równe prawa na skalę całego kraju. Niezwykle istotne było również to, iż wyrok Sądu Najwyższego uruchomił prawdziwą lawinę działań prawnych na rzecz zniesienia segregacji a sama sprawa „(...) uzbroiła (...) masy murzyńskie i ich białych sojuszników w oręż prawny do zwalczania segregacji”"

Drugą ,"iskrą" stała się sprawa, o wydawałoby się, dużo mniej znaczącym charakterze, która mimo to uzyskała ogromny rozgłos w całych Stanach Zjednoczonych. W miasteczku Money w stanie Mississipi, 28. sierpnia 1955 r., zamordowany został młody chłopiec - Emmett Till. Padł ofiarą dwóch białych mężczyzn z tego jedynie powodu, iż po kupieniu słodyczy w sklepie odezwał się do białej dziewczynki. Emmett Till nie wychował się na Południu i nie był obeznany z niepisanymi „prawami i obowiązkami” Afroamerykanów, które dotyczyły także stosunków (a właściwie ich braku) z białymi kobietami. Pochodził z Chicago, z północnego stanu Illinois i w tamtym mieście miał białych przyjacióf. W Money, a i na całym Południu rzeczywistość kształtowała się jednak inaczej i jego zachowanie łamało podstawowe zasady interakcji między rasami, musiało więc zostać przez lokalną społeczność białych przykładnie ukarane.

Sprawców morderstwa złapano następnego dnia po zabójstwie i postawiono przed sądem. W tydzień po tym wydarzeniu zdjęcia martwego Emmetta Tilla obiegły całą Amerykę opublikowane w magazynie „Jet”. 23. września, niecały miesiąc po dokonaniu tego okrutnego zabójstwa obaj oskarżeni zostali oczyszczeni z zarzutów przez białą ławę przysięgłych (mimo, że wcześniej przyznali się do zarzucanych im czynów. Wyrok ławy przysięgłych opierał się na argumentacji, iż prokuratorowi nie udało się udowodnić, że prezentowane ciało należy do Emmeta Tilla. A skoro nie zostało to udowodnione, to nie można mówić o popełnieniu morderstwa ${ }^{9}$ ). Wyrok ten zbulwersował Afroamerykanów w całym kraju, szczególnie jednak na Północy, jako że ofiarą rasistowskiego systemu padł mieszkaniec Chicago. W pogrzebie chłopca uczestniczyło ponad 50 tysięcy Czarnych. Sprawa Emmetta Tilla zjednoczyła Afroamerykanów w całej Ameryce, gdyż ukazała jak bardzo niebezpieczne dla wszystkich czarnoskórych Amerykanów mogą być praktyki stosowane na Południu. Matka Emmetta - Mammie Till, w jednej z wypowiedzi wyraziła znaczenie, jakie miała ta sprawa dla zwiększenia poczucia wspólnoty wśród Afroamerykanów: „Dwa miesiące temu miałam dobre mieszkanie w Chicago. Miałam dobrą pracę. Miałam syna. Gdy coś (złego - przyp. J. J.) działo się z Murzynami na Południu mówiłam, że to ich sprawa, nie moja. Teraz wiem, jak bardzo się myliłam. Zamordowanie mego syna ukazało mi, że cokolwiek stanie się komukolwiek z nas (Afroamerykanów - przyp. J. J.), gdziekolwiek na świecie, musi to być sprawą nas wszystkich" ${ }^{\prime 10}$.

Zdanie Mamie Till zaczęły podzielać miliony czarnoskórych Amerykanów, a sprawa Emmeta Tilla mogła mieć nawet większy wpływ na masy Czarnych niż decyzja sądu w sprawie

$8 \quad$ S. Brodzki, Czarny problem USA, Warszawa 1968, s. 135.

9 Por. L. Cozzens, The Murder of Emmett Till. African American History,

http://www.watson.org/ lisa/blackhistory/early-civilrights/emmett.html, 20.11.2010.

10 Tamże. 
Brown przeciwko zarządowi szkół w Topeka. Bezsensowność brutalnego mordu oraz absurdalność wyroku uniewinniającego zabójców wpłynęły na świadomość ogromnej ilości Afroamerykanów i wielu zmotywowały do działania, by taka sytuacja już się nie powtórzyła. Jak się miało okazać, nawet bezprawie może mieć swoje granice i w tym wypadku granicę przekroczyła śmierć niewinnego, czarnoskórego chłopca.

Pierwszym, ale jednocześnie przełomowym dowodem na twierdzenie, iż zjednoczeni Afroamerykanie byliby w stanie skutecznie przeciwstawić się aparatowi opresji ze strony białego społeczeństwa, było wydarzenie, które stanowi trzecią i ostatnią z „iskier”, które spowodowały pożar - bojkot autobusów w Montgomery.

1. grudnia 1955 r., wracając późnym wieczorem z pracy, mieszkanka Montgomery, Rosa Parks, zajęła miejsce, jak określały to rasistowskie przepisy, z tyłu autobusu. Gdy po przejechaniu przez autobus kilku przystanków zapełnione zostały wszystkie miejsca przeznaczone dla białych, kierowca nakazał Rosie Parks ustąpić miejsca białemu pasażerowi, co jednak spotkało się z odmową z jej strony. W rezultacie wezwana została policja, a kobieta została aresztowana. Obyło się bez protestów ze strony reszty czarnoskórych pasażerów. Nie doszło także do żadnych starć z policja, czy też wybuchów przemocy. Cały incydent wydawał się być nie znaczącym, kolejnym przejawem praw panujących na Południu USA. Jednakże jeszcze w nocy 1. grudnia podjęto decyzję o rozpoczęciu bojkotu autobusów, który miał trwać aż 381 dni i zakończyć się zniesieniem segregacji w autobusach Montgomery. Ów Bojkot był też wydarzeniem, w którym po raz pierwszy czołową rolę odegrał Martin Luther King - dwudziestopięcioletni, nieznany jeszcze wtedy pastor. Pastor, który niecałe dziesięć lat później miał zostać uhonorowany Pokojową Nagrodą Nobla za swoje działania w sprawie pokojowego uzyskania praw obywatelskich przez Afroamerykanów.

Podczas tej, trwającej ponad rok akcji protestacyjnej ukształtowała się także pewna forma walki o prawa obywatelskie określana mianem biernego oporu (nonviolent resistance), która była stosowana w całych Stanach Zjednoczoncych przez kolejne kilkanaście lat. Poza tym „od czasów zajść w Montgomery datuje się rozwój masowych form walki" ${ }^{\prime 11}$, a w efekcie owych działań „(...) po raz pierwszy w dziejach Murzynów amerykańskich zaczął powstawać masowy ruch murzyński"121 W akcjach protestacyjnych w Montgomery udział wzięło 50 tysięcy Afroamerykanów. Liczba ta stanowiła wtedy około $99 \%$ wszystkich czarnoskórych mieszkańców miasta ${ }^{13}$, co stanowiło dowód, iż Afroamerykanie potrafią się zjednoczyć w walce z dyskryminacją i wygrać tę batalię.

Zachowanie Rosy Parks i bojkot autobusów w Montgomery znacznie częściej uznawane są za symboliczną datę rozpoczęcia Rewolucji Czarnych, ze względu na swój bezpośredni związek z masowymi demonstracjami, które właśnie w Montgomery po raz pierwszy miały miejsce. Jednakże wszystkie przedstawione przeze mnie wydarzenia są ze sobą ściśle powiązane i ukazują wieloaspektowość samej „trzeciej rewolucji amerykańskiej”. Decyzja Sądu Najwyższego Stanów Zjednoczonych z 1954 r. ukazała, że Afroamerykanie są w stanie udowodnić bezprawność rasistowskich przepisów i uzyskać ich delegalizację. Morderstwo Emmeta Tilla ukazało brutalne zagrożenie usankcjonowanego prawnie rasizmu, oraz stało się symbolem wagi, jakie ma natychmiastowa, ogólnonarodowa walka z dyskyminacją Afroamerykanów. Walka, którą muszą przeprowadzić sami Afroamerykanie, nie tyko Ci mieszkający na Południu. Zaś bojkot autobusów w Montgomery stał się żywym dowodem na możliwość uzyskania praw, o które Czarni zaczęli walczyć własnymi siłami.

11 S. Brodzki, Czarny problem..., dz. cyt., s. 137.

12 W. Osiatyński, Korzenie "Korzeni”, Warszawa 1981, s. 221.

13 S. Brodzki, Czarny problem ..., dz. cyt., s. 137. 
Dlatego też, w związku z tym, iż każde z tych wydarzeń na swój sposób zapoczątkowało Rewolucję Czarnych, wszystkie trzy mogą być moim zdaniem określane mianem „iskier", które spowodowały pożar - zintensyfikowane, ogólnonarodowe działania mające na celu walkę z dyskryminacją rasową. Ten wielowymiarowy proces nie ustawał przez ponad dekadę i obejmował m.in. legalne i nielegalne akcje protestacyjne, akcje rejestracji czarnoskórych wyborców, działania mające wywrzeć presję legislacyjną na szczeblu stanowym i federalnym, zakładanie przez Czarnych partii politycznych oraz organizacji wspierających rozwój społeczności Afro-amerykanów, zwiększoną aktywność religijnych organizacji skupiających czarnoskórych Amerykanów (w tym np. Nation of Islam) i wiele innych. Ów rewolucyjny „pożar” nie został ugaszony, dopóki nie zostały uchwalone tzw. ustawy o prawach obywatelskich z lat 1964 i 1968, i Afroamerykanie nie wygrali wojny z systemem prawnej segregacji, i dyskryminacji rasowej. Wojny, która zakończyła erę usankcjonowanego prawnie rasizmu w Stanach Zjednoczonych, ale nie zlikwidowała rasizmu i dyskryminacji rasowej w amerykańskim społeczeństwie, co dobitnie potwierdzają niezliczone przykłady od niesławnego pobicia Rodney'a King'a przez policjantów z Los Angeles (później uniewinnionych przez, w większości biała, ławę przysięłych pomimo tego, iż całe zajście zostało zarejestrowane na wideo), poprzez stereotypowe, dwuwymiarowe obrazowanie Czarnych w amerykańskich filmach, aż po zamieszki w dzielnicy Watts w Los Angeles z 1992 r.. Pytanie o metodę rozwiązania tego palącego problemu od lat pozostaje bez satysfakcjonującej odpowiedzi.

\section{Bibliografia}

Baldwin J., Na spotkanie człowieka, Warszawa 1971.

Baldwin J., Następnym razem pożar, Warszawa 1965.

Brodzki S., Czarny problem w USA, Warszawa 1968.

Brogan H., Historia Stanów Zjednoczonych Ameryki, Wrocław 2004.

Brown Tindall G., Shi E. D., Historia Stanów Zjednoczonych, Poznań 2002.

Eyes on the prize, part 11 - we ain't gonna shuffle no more, reż. Sam Pollard, Sheila Bernard, PBS, USA, 1987.

Goldston R., The Negro revolution, New York 1969.

King L. M., Dlaczego nie możemy czekać, Warszawa 1967.

Lomax L. E., Bunt Murzynów, Warszawa 1966.

Ludwikowski R. R., Murzyński radykalizm w USA, Warszawa 1976.

Oates S. B., Let the trumpet sound. The life of Martin Luther King, New York 1985.

Orton L. D., Dwieście lat USA, Ideały i paradoksy historii amerykańskiej, Warszawa 1984.

Osiatyński W., Korzenie „Korzeni”. Dzieje Murzynów w Stanach Zjednoczonych, Warszawa 1981.

Rokicki J., Kolor, pochodzenie, kultura, Kraków 2002.

Rusinowa I., Tom czy Sam. Z dziejów Murzynów w Ameryce Pótnocnej, Warszawa 1983.

Warren R. P., W imieniu Murzynów, Warszawa 1974.

\section{Netografia}

Cozzens L., African American History, http://www.watson.org/ lisa/blackhistory/contents.html, 20.11.2010.

Kowalewski Z. M., Rap - między Malcolmem X a subkulturą gangowa, e-book, edycja 10.02.2008.

http://www.pbs.org/wgbh/amex/eyesontheprize/story/index.html, 10.11.2010.

\section{Słowa kluczowe}

Afroamerykanie, Ruch na Rzecz Praw Obywatelskich, równouprawnienie, rasizm, Trzecia Rewolucja Amerykańska, walka z dyskryminacją rasową

\section{STRESZCZENIE}

W moim artykule przybliżyłem genezę największego sprzeciwu Afroamerykanów wobec 
rasowej segregacji i prawnej dyskryminacji w Stanach Zjednoczonych, którego esencję stanowił Ruch na Rzecz Praw Obywatelskich zapoczątkowany w połowie lat pięćdziesiątych XX wieku. Skoncentrowałem się na trzech wydarzeniach, które stały się symbolicznymi wyznacznikami początku Rewolucji Czarnych, jak określa się wydarzenia lat 1954 - 1968. Poruszone zostały kwestie przyczyn i uwarunkowań wybuchu tego masowego ruchu walki Afroamerykanów z dyskryminacją i znaczenia tych wydarzeń dla Afroamerykanów i społeczeństwa amerykańskiego. Trzy tytułowe „iskry”, których analizy się podjąłem, dotyczą różnych aspektów życia i pozornie wydają się nie być ze sobą związane. Cóż może mieć ze sobą wspólnego morderstwo młodego, czarnoskórego chłopca, decyzja Sądu Najwyższego Stanów Zjednoczonych oraz bojkot publicznych środków transportu? W artykule starałem się wykazać, że poszukując genezy wybuchu Rewolucji Czarnych niechybnie natrafiamy na te trzy wydarzenia i trudno jest przeoczyć ich ogromne znaczenie dla Ruchu na Rzecz Praw Obywatelskich.

\section{SPARKS THAT CAUSED THE FIRE. THREE EVENTS WHICH INITIATED the Civil Rights Movement in the United States}

\section{Keywords}

Afro-Americans, Civil Rights Movement, equal rights, racism, Third American Revolution, struggle against racial discrimination.

\section{Summary}

In the paper I examine the genesis of the largest opposition of Afro-Americans against the racial segregation and legal discrimination in the United States, whose essence is the Civil Rights Movement initiated in the mid 1950s. I focused on the three events, which have become the symbolic determinants of the beginning of the Black Revolution, as the events of the 1954-1968 are called. The questions of causes and determinants of the rising of this mass movement of Afro-Americans' struggle against discrimination as well as the meaning of those events for the Afro-Americans and the American society have been touched. The three eponymous "sparks", which I further analyze, refer to the various aspects of life and seemingly are not connected to each other. What may the murder of a young black boy, the verdict of the Supreme Court of the United States and the boycott of the public transport have in common? In the paper I attempt to prove, that when searching for the genesis of the breakout of the Black Revolution, one will inevitably come across those three events and it is difficult to overlook their great importance in regard to the Civil Rights Movement. 